\title{
Topographic analysis of K-ras mutations in histologically normal lung tissues and tumours of lung cancer patients
}

\author{
P Keohavong ${ }^{1,5}$, HH Mady ${ }^{2,6}$, WM Gao', JM Siegfried ${ }^{3,5}$, JD Luketich ${ }^{4,5}$ and MF Melhem ${ }^{2,6}$ \\ Departments of ${ }^{1}$ Environmental and Occupational Health, ${ }^{2}$ Pathology, ${ }^{3}$ Pharmacology, and ${ }^{4}$ Surgery, and ${ }^{5}$ University of Pittsburgh Cancer Institute, University of \\ Pittsburgh, Pittsburgh, PA 15213, and, ${ }^{6}$ the Veterans Administration Health Care System, Pittsburgh, PA 15240, USA
}

\begin{abstract}
Summary Mutations in the K-ras gene are very common in lung tumours and are implicated in the development of lung cancer, but the timing of their occurrence remains poorly understood. We investigated K-ras mutations in cell samples microdissected by laser capture microscopy at multiple sites from lung tissue sections representing tumour tissue and matched histologically normal tissue obtained from 48 lung cancer patients. K-ras mutations were detected in cell samples from 10 of $38(26.3 \%)$ lung adenocarcinomas and in none of the histologically normal or tumour cell samples taken from 10 lung squamous cell carcinomas. Of the K-ras mutation-positive adenocarcinomas, in 4 cases a mutation was found in only the tumour tissue, in 1 case a mutation was found only in the histologically normal tissue, and in 5 cases mutations were found in both the tumour tissue and histologically normal tissue. Among these 5 cases, 2 had identical mutations in both the tumour tissue and histologically normal tissue, 2 had 1 mutation in the tumour tissue and 2 mutations in the histologically normal tissue, 1 of which was identical to the mutation found in the tumour, and 1 case had 2 codon 12 mutations in tumour tissue and 2 mutations, in codons 9 and 11 , in histologically normal tissue. These results showed that K-ras mutations are frequent in histologically normal cells taken from outside lung adenocarcinomas and suggest that some of these mutations may represent early events which could pave the way of lung carcinogenesis. (c) 2001 Cancer Research Campaign http://www.bjcancer.com
\end{abstract}

Keywords: lung carcinoma; ras oncogene; laser capture microdissection; denaturing gradient gel electrophoresis

Lung cancer kills both men and women in the United States more than any other type of cancers, causing an estimated 156900 deaths in 2000 and accounting for $28 \%$ of all cancer deaths, in spite of improved therapy available and nationwide anti-smoking campaign (Cancer Facts and Figures - 2000, American Cancer Society). Extensive studies have shown that the development of lung cancer, like many other cancers, is a multistep process which takes several years and proceeds presumably through a series of molecular events leading to an accumulation of genetic variation including mutational, chromosomal and epigenetic changes (Harris, 1991; Sozzi et al, 1995; Stanley, 1995). In this paradigm, one major pathway to lung malignancy involves structural alterations of cancer-related genes, including activation of dominant oncogenes and inactivation of tumour suppressor genes (Barbacid, 1987; Bishop, 1991; Hollstein, 1991; Gazdar, 1994; Stanley, 1995)

The K-ras oncogene has been frequently found in mutated form in lung tumours and cell lines; K-ras mutations are often associated with the development of lung cancer. This gene codes for a $21-\mathrm{kd}$ protein (ras), which is related to the G proteins which bind guanine nucleotides with high affinity and are located at the inner surface of the cell membrane. These proteins have an important role in the signal transduction pathway (Barbacid, 1987; Bishop, 1991; Khosravi-Far and Der, 1994). Activation of the ras genes occurs with specific point mutations at only a very few codons

Received 19 January 2001

Revised 23 April 2001

Accepted 30 April 2001

Correspondence to: P Keohavong including codons 12,13 or 61 , with codon 12 being mutated in more than $90 \%$ of K-ras mutations identified in lung tumours (Suzuki et al, 1990; Sugio et al, 1992; Rodenhuis and Slebos, 1992; Husgafvel-Pursiainen et al, 1993; Rosell et al, 1996; Keohavong et al, 1996). These mutations induce structural changes within the ras proteins leading to an 'activated' GTPbound conformation.

Lung cancer has been grouped into 4 major histologic types, including adenocarcinoma, squamous cell carcinoma, large cell carcinoma, and small cell lung carcinoma (SCLC). The first 3 types are termed collectively non-small cell lung carcinoma (NSCLC) and have different clinical features from SCLC (Minna et al, 1989). K-ras mutations occur in $15 \%$ to $50 \%$ of adenocarcinoma and large cell undifferentiated carcinoma of the lung. Particularly, they have been more frequently found in tumours from smokers $(21-35 \%)$ than in those from nonsmokers $(5-7 \%)$, suggesting their formation may be associated with tobacco smoke exposure. They have also been found, but at a lower frequency, in other forms of pulmonary neoplasia, including squamous cell carcinoma (Suzuki et al, 1990; Sugio et al, 1992; Rodenhuis and Slebos 1992; Husgafvel-Pursiainen, 1993; Rosell et al, 1996; Keohavong et al, 1996, 1997a).

Although K-ras mutations have been frequently found in lung tumours, the timing of their occurrence in the multistep process of lung carcinogenesis remains poorly understood. Such studies used tissue specimens removed at biopsy or resection (Sugio et al, 1992; Westra et al, 1993; Clements et al, 1995; Yakubovskaya et al, 1995; Urban et al, 1996; Keohavong et al, 1997b; Urban et al, 2000), and cell samples microdissected from embedded lung tissue sections (Sugio et al, 1994; Westra et al, 1996). Taken 
together, some of these studies suggest that K-ras mutations occur relatively late in lung cancer development (Sugio et al, 1994; Yakubovskaya et al, 1995; Urban et al, 1996), while other studies indicate that they could represent early events in this process $(\mathrm{Li}$ et al, 1994; Clements et al, 1995; Keohavong et al, 1997b; Urban et al, 2000).

We have previously applied a sensitive method to analyse and compare K-ras mutations in lung tumour and matched tumouradjacent histologically normal tissues (Keohavong et al, 1997). We have reported that histologically normal tissues taken from outside K-ras-mutated lung tumours contained a low fraction of the mutational genotype identical to those found in the corresponding tumour in 4 of 8 lung cancer patients. However, the fact that such a study used tissue samples that each contained several hundreds cells, there were some concerns that the low fraction mutations detected in the histologically normal tissues might have originated from a contamination with very few tumour cells or mutated DNA diffusing from necrotic tumour cells in surrounding tissues, although we took all precautions to avoid or at least minimize such a possibility (Keohavong et al, 1997b). In this study, we applied a laser capture microdissection technique to histopathologically review and precisely sample, under direct microscope visualization, a few cells from various areas of paraffin-embedded lung tissue sections, including histologically normal tissue and matched tumour tissue, obtained from 48 cases of lung cancer patients. We analysed K-ras mutations in each cell sample using polymerase chain reaction and denaturing gradient gel electrophoresis. The results demonstrate that K-ras mutations are present in histologically normal tissue surrounding lung tumour in about $15.8 \%$ (6 of 38 ) of patients with lung adenocarcinoma. We compared these results with those reported previously by us and others and discussed them in relation to the role of K-ras mutations in lung carcinogenesis and as potential surrogate biomarkers for lung cancer.

\section{MATERIALS AND METHODS}

\section{Patients and tissue specimens}

Pulmonary lobectomy specimens were obtained from 48 patients with lung cancer, including 38 adenocarcinoma and 10 squamous cell carcinoma. The demographic and clinical information is shown in Table 1. These specimens were formalin-fixed and paraffin- embedded and stored at the University of Pittsburgh Medical Center between 1990 and 1999. The diagnosis of lung adenocarcinoma and squamous cell carcinoma was confirmed, using established morphologic criteria. For DNA analysis, $5 \mu \mathrm{m}$ histologic sections were prepared from multiple paraffin blocks representative of tumour and those representative of matched histologically normal lung tissues (located between $2.0 \mathrm{~cm}$ and 5.0 $\mathrm{cm}$ from the tumour edge). These normal tissues corresponded to either bronchial or bronchiolar pseudostratified columnar epithelial tissues that matched tumours (adenocarcinoma or squamous cell carcinoma) of a bronchial origin, or alveolar walls that matched tumors (adenocarcinoma or bronchoalveolar type) of an alveolar origin. All tissue sections were individually deparaffinized in xylene and then in ethanol, rinsed with water, and airdried. All slides were stained with hematoxylin and eosin and reviewed to confirm the presence of histologically normal tissue and/or tumour. The microdissection was performed by a trained pathologist using a laser capture microdissection microscope
(PixCell II LCM System, Arcturus Engineering, Mountain View, CA). With the aid of this new technique, individual cells within areas of interest of a tissue section were isolated (Emmert-Buck et al, 1996). Areas of tumour tissue and histologically normal tissue were prepared and microdissected separately to avoid any possible cross-contamination between tissues. Samples of 100-200 histologically normal cells or malignant cells were 'lasercaptured' on separate 'Caps' built to fit a $0.5 \mathrm{ml}$ microcentrifuge tube (Acturus Engineering, Mountain View, CA). Each cell sample was considered to be $100 \%$ 'homogeneously' normal-appearing or malignant, as determined by a careful microscopic visualization of the cells captured on each Cap.

\section{DNA extraction and K-ras codon 12 mutation analysis}

The captured cells were lysed by adding directly on each Cap 20 $\mu \mathrm{l}$ of lysis solution (40 mM Tris-HCl, $\mathrm{pH}$ 8.0, 1 mM EDTA, 0.5\% Tween-20, and $0.5 \mu \mathrm{g} \mu \mathrm{l}^{-1}$ proteinase K) (Sugio et al, 1994). The Cap was enclosed into a $0.5 \mathrm{ml}$ microcentrifuge tube (in an upsidedown position) and incubated at room temperature for 48 hours with occasional gentle shaking. The resulting cell lysate was recovered in the tube by a quick and gentle spinning in a microcentrifuge then heated at $95^{\circ} \mathrm{C}$ for 5 minutes to inactivate the proteinase K. Half $(10 \mu \mathrm{l})$ of each cell lysate was used as template for a first round of PCR to amplify a 75-bp genomic fragment containing the $5^{\prime}$ half of exon 1 of the K-ras gene and adjacent flanking intron sequence. PCR was carried out in a final $50 \mu 1$ reaction mixture containing $10 \mathrm{mM}$ Tris- $\mathrm{HCl}, \mathrm{pH} 8.3,1.5 \mathrm{mM}$ $\mathrm{MgCl}_{2}, 50 \mathrm{mM} \mathrm{KCl}, 100 \mu \mathrm{M}$ each dNTP, $0.5 \mu \mathrm{M}$ each primer and 2.5 units of Gold AmpliTaq DNA polymerase (Perkin Elmer, CT). The mixture was heated at $95^{\circ} \mathrm{C}$ for 9 minutes then subjected to 15 cycles $\left(94^{\circ} \mathrm{C} / 1\right.$ minute, $53^{\circ} \mathrm{C} / 1$ minute, $72^{\circ} \mathrm{C} / 1$ minute), using the primers KI1-1 (sense): 5' - TATTATAAGGCCTGCTGAAA-3' and PKB (antisense): 5'- AGGCACTCTTGCCTACGGCA-3'. For the second round of PCR, $2 \mu \mathrm{l}$ of the PCR products from the first round were diluted into a final $25 \mu \mathrm{l}$ reaction mixture containing the same buffer composition as above except that $0.25 \mu 1$ of $[\alpha-$ $\left.{ }^{32} \mathrm{P}\right]$-dATP $(3000 \mathrm{Ci} / \mathrm{mmol}$, New England Nuclear, Boston, MA) was added and primer KI1-1 was replaced by primer PKGC: $5^{\prime}$ GCCGCCTGCAGCCCGCGCCCCCCGTGCCCCCGCCCCGCCGCCGGCCCGGCGCCTATAAGGCCTGCTGAAAATG-3'. The mixture was heated at $95^{\circ} \mathrm{C}$ for 9 minutes then subjected to 35 PCR cycles $\left(94^{\circ} \mathrm{C} / 1\right.$ minute, $60^{\circ} \mathrm{C} / 1$ minute, $72^{\circ} \mathrm{C} / 1$ minute). The resulting PCR products were separated by gel electrophoresis and autoradiographed. Band containing the expected-size 126-bp fragment was excised from the gel. DNA was eluted from the gel slice and analysed by DGGE (Bio-Rad, CA) under the conditions described previously (Keohavong et al, 1997b). Mutant alleles were isolated from the denaturing gradient gel and further characterized by sequencing. This method allows us to clearly detect a $\mathrm{K}-$ ras mutant allele present at a mutant fraction of $5 \%$ (1 mutant allele among 20 wild-type alleles) (Keohavong et al, 1997b). This level of sensitivity should be sufficient to identify K-ras mutations in DNA samples from an equivalent 50-100 original cells. In the cases where mutant alleles appeared ambiguous by using the above PCR+DGGE method, a more sensitive version of this method which has a detection limit of $10^{-3}-10^{-4}$ (one mutant allele in $10^{3}-10^{4}$ wild-type allele) was used. This method requires an additional step for mutant allele enrichment involving a prior treatment of the 126-bp amplified fragment with Ban I restriction enzyme which cleaves fragments with a non-mutated K-ras codon 
12. The digestion-resistant fragment was gel-purified and analysed by DGGE as described previously (Keohavong et al, 1997b).

\section{RESULTS}

\section{Lung tissue sampling and microdissection}

Figure 1 shows a representative example of a target-site sampling from a case of lung adenocarcinoma. The use of a laser capture microscopy allowed an accurate morphologic analysis and precise sampling of cells from areas of interest in paraffin-embedded tissue sections. Histologically normal cells were individually resected by laser capture from the tissue area located between $2 \mathrm{~cm}$ and $5 \mathrm{~cm}$ from the edge of the tumour area. Between 100 and 200 cells were captured on each Cap after a careful histologic examination and determination of their benign morphology. All cells appeared homogeneously normal-looking and there were no tumour cells present. Paraffin-embedded tissue blocks representative of tumour tissue were topographically sampled in a similar manner. The cells captured from the tumour tissue also all appeared malignant histologically. After microdissection, each captured cell sample was compared to the matched tissue section prior to and after microdissection to confirm the accuracy of target selection (see Figure 1A-D). Using this approach, we prepared 38 cell samples from histologically normal tissue and 38 cell samples from matched malignant tissue from paraffin-embedded lung tissue sections selected from 38 patients with lung adenocarcinoma. We also prepared cell samples from histologically normal tissue, matched metaplasia and tumour tissue from paraffinembedded tissue sections obtained from 10 patients with lung squamous cell carcinoma.

\section{Mutation analysis}

Molecular analysis of the above cell samples using the PCR+DGGE method yielded 10 lung cancer cases showing K-ras mutant alleles in tumour cells and/or paired histologically normal cells, all of which corresponded to lung adenocarcinoma $(26.3 \%$ or 10 of 38 cases). Figure 2 shows an example of DGGE separation of K-ras mutant alleles from the wild-type allele for 6 of the 10 $\mathrm{K}$-ras mutant-positive cases. The mutant alleles were isolated from the gel and the nature of the mutations was determined by
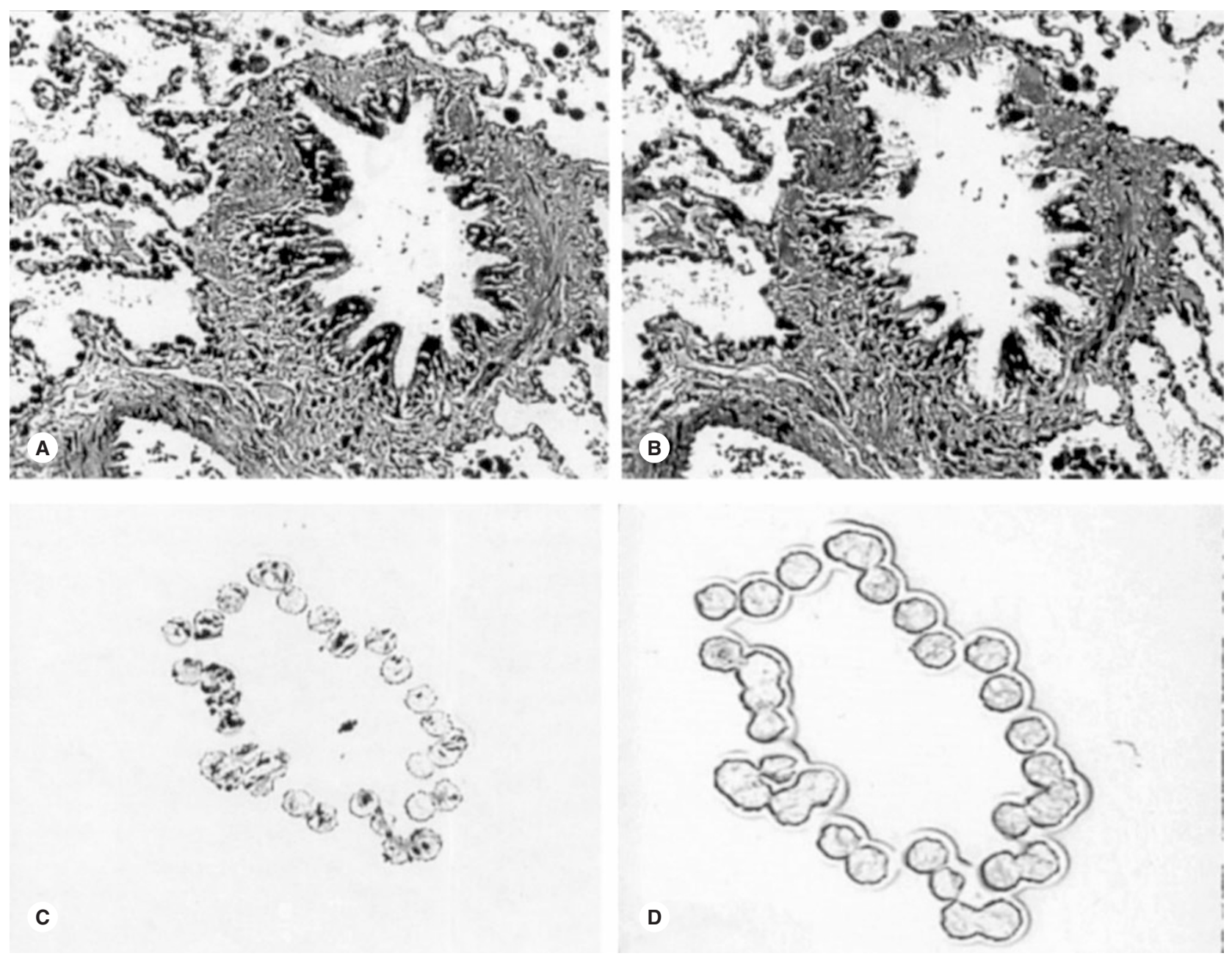

Figure 1 An example of tissue site sampling from a formalin-fixed and paraffin-embedded tissue section from one case of lung adenocarcinoma (see patient 4 in Table 1) by using a laser capture microdissection microscope (magnification $\times 100$ ). The figure shows a tissue section obtained from a block representative of a histologically normal lung tissue pre- (A) and post- (B) topographic microdissection of normal-appearing cells from an area of interest of the tissue section. The cells were 'captured' on a Cap (C) and reviewed further for cell population homogeneity and then treated with proteinase K. (D) shows the same cell sample after treatment with proteinase K, with the cellular content being totally lysed. Under the lysis conditions shown in Materials and Methods, between $95 \%$ and $100 \%$ of the captured cells were completely lysed 


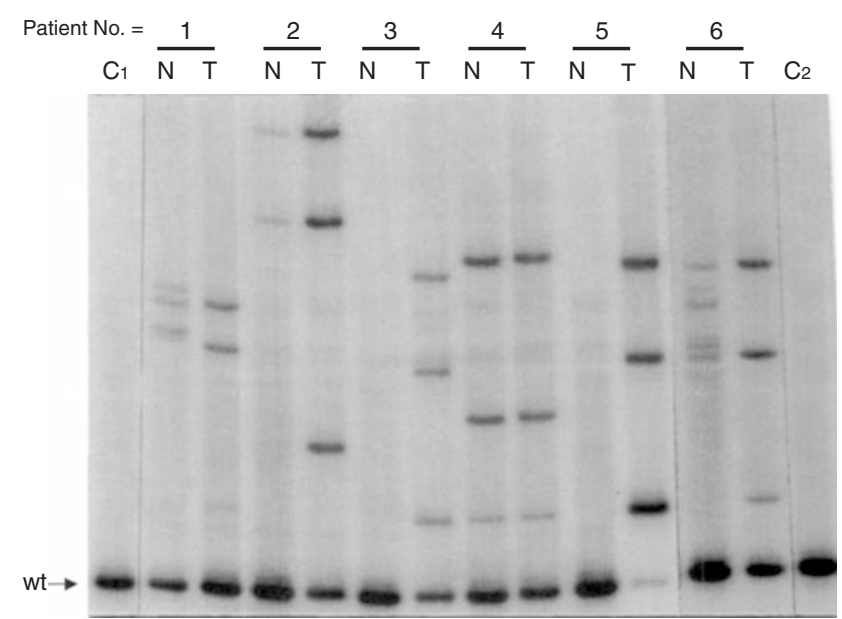

Figure 2 DGGE analysis of K-ras mutations, K-ras gene exon 1 is amplified from cellular DNA isolated from each cell sample microdissected from histologically normal $(\mathrm{N})$ and tumour $(\mathrm{T})$ areas of a selected lung tissue section as shown in Figure 1. The amplified DNA is analysed by DGGE to separate any K-ras mutant allele that may be present in each cell sample from the wild type allele. The figure shows sequence patterns of K-ras mutant alleles for 6 of 10 lung adenocarcinoma that were found to be positive for Kras mutation in the tumour tissue and/or the histologically normal tissue. The wild-type allele was present in excess over mutant allele(s) in each DNA sample, except for the tumour DNA sample in patient 5 , and was detected as a homoduplex fragment (wt). The presence of a mutant allele was detected as 3 additional fragments, including a mutant homoduplex and the 2 respective mutant/wild-type heteroduplexes that separated from the wild-type fragment in lower denaturant concentrations from the bottom to the top of the gel, respectively. In patient 1, the histologically normal DNA sample showed 4 mutant/wild-type heteroduplexes that corresponded to the presence of 2 different mutant alleles (see patient 1 in Table 1). Lanes $C$ show the sequence patterns of negative control DNA samples corresponding to a known K-ras mutation-negative benign lung tissue (C1) and infant normal intestine tissue (C2). The histologically normal tissue sample $(\mathrm{N})$ in patient 6 contained several faint heteroduplex bands. Further experiments showed that only the 2 heteroduplexes identical to those appearing in the matched tumour sample $(\mathrm{T})$ were repeatedly detected. Therefore, the presence of the other heteroduplexes in the histologically normal tissue sample $(\mathrm{N})$ was presumably due to experimental variation

sequencing. No mutants were identified in any of the cell samples corresponding to tumour tissue or paired histologically normal tissue obtained from the 10 cases of squamous cell carcinoma (data not shown). These results are in line with previous studies showing that K-ras mutations were frequently identified in lung adenocarcinoma but were rarely so in lung squamous cell carcinoma (Rodenhuis and Slebos, 1992; Husgafvel-Pursiainen et al, 1993; Keohavong et al, 1996). As shown in Figure 2, the 2 control samples of known normal tissues ( $\mathrm{C} 1$ and $\mathrm{C} 2)$ revealed only the $\mathrm{K}$-ras codon 12 wild-type homoduplex (wt). Compared with the controls, patients 3 and 5 showed each a mutant pattern in the tumour tissue but not in the paired histologically normal tissue. These patients harboured each a GGT to TGT mutation in their lung tumour tissue. In addition, in patient 5 , the wild-type allele appeared only as a small fraction of the mutant allele in this tumour sample $(\mathrm{T})$. This observation may indicate that some tumour cell in this sample may have lost 1 allele of K-ras gene while containing a mutation in the remaining allele. This loss of the wild-type allele appeared to occur at a specific area of the tumour tissue because further analysis of tumour cells taken from 2 separate sites of tumour tissue from this patient showed not only the TGT mutation but also the wild-type allele at a fraction higher than the TGT mutant allele in both samples (data not shown). Nevertheless, the presence of a loss of 1 allele and a mutation in the other allele of the K-ras gene has not been reported previously. It may be that the deletion of the wild-type allele occurred as a secondary event that accumulated during the progression of cells with already a K-ras mutated gene in one allele into tumour. Patients 2, 4 and 6 each harboured a genotypically identical mutation in both the tumour tissue and the paired histologically normal tissue, corresponding to a GGT to TTT, a GGT to GTT, and GGT to TGT, respectively. Patient 1 showed 4 mutant/wild-type heteroduplexes in the histologically normal tissue $(\mathrm{N})$, which were found to correspond to 2 different mutations, a GTT to ATT in codon 9, and a GCT to ACT in codon 11, of the K-ras gene. This patient also showed two mutant/wild-type heteroduplexes in the matched tumour tissue (T), which corresponded to a GGT to GAT mutation in codon 12 of the K-ras gene.

\section{Multiple site analysis of $\mathrm{K}$-ras mutations}

In order to investigate in more detail the topographic distribution of mutations in each lung tumour tissue and histologically normal tissue, all $10 \mathrm{~K}$-ras mutation-positive adenocarcinomas as well as $3 \mathrm{~K}$-ras mutation-negative adenocarcinomas were re-examined further for K-ras mutations. Toward this end, between 3 and 5 additional successive tissue sections were prepared from original tissue blocks representing tumour-surrounding histologically normal tissue as well as those representing tumour tissue for each cancer case. Table 1 summarizes the final results of K-ras mutations identified at multiple sites in both the histologically normal tissue and the matched tumour tissue for the 10 cases of K-ras mutation-positive lung adenocarcinomas. The cell samples obtained from the tumour tissue and histologically normal tissue for the 3 selected K-ras mutation-negative patients were all found to be negative for K-ras mutations (data not shown), confirming the results of the first experiment. 4 of the $10 \mathrm{~K}$-ras mutationpositive cases (Patients 3, 5, 7 and 8) contained each a mutation (a GGT to TGT) in only the tumour tissue. This mutation was present in all malignant cell samples taken from 3 different areas of the tumour tissue from each of these patients. Patients 2 and 6 each contained a genotypically identical mutation (a GGT to TTT and GGT to TGT, respectively) in both the tumour tissue and matched histologically normal tissue. These mutations were present in all cell samples taken from 3 different tissue blocks representative of the normal-appearing tissue and those representative of the matched tumour tissue obtained from these patients, in agreement with the results of the first experiment shown in Figure 2 for these patients. Likewise, multiple site analysis helped confirm that Patient 4 contained a genotypically identical mutation, a GGT to GTT, in both the tumour tissue and histologically normal tissue. In addition, as shown in Figure 3, a second mutation, a GGT to AGT, was detected in the histologically normal tissue. However, while the GGT to GTT mutation was found in all tissue blocks representative of the histologically tissue (see lanes $\mathrm{N} 1, \mathrm{~N} 2$ and $\mathrm{N} 3$ and $\mathrm{n} 1 \mathrm{n} 2$, and $\mathrm{n} 3$ ), as well as those representative of the tumour tissue (see T1, T2 and T3), the GGT to AGT mutation was found in only cell samples taken from one specific area of the histologically normal tissue (see lanes N1 and n1). This tissue area was defined at the margin of resection located $5 \mathrm{~cm}$ from the edge of the tumour. In the remaining 3 patients (Patients 1, 9 and 10; Table 1), the mutations were identified at a low fraction as shown by the fact they were identified only in 1 or 2 of the total 6 cell samples taken from the histologically normal tissue and/or the tumour tissue and by only using a more sensitive version of the 
Table 1 Summary of K-ras mutations in lung tissue sections from 10 cases of lung adenocarcinoma ${ }^{a}$

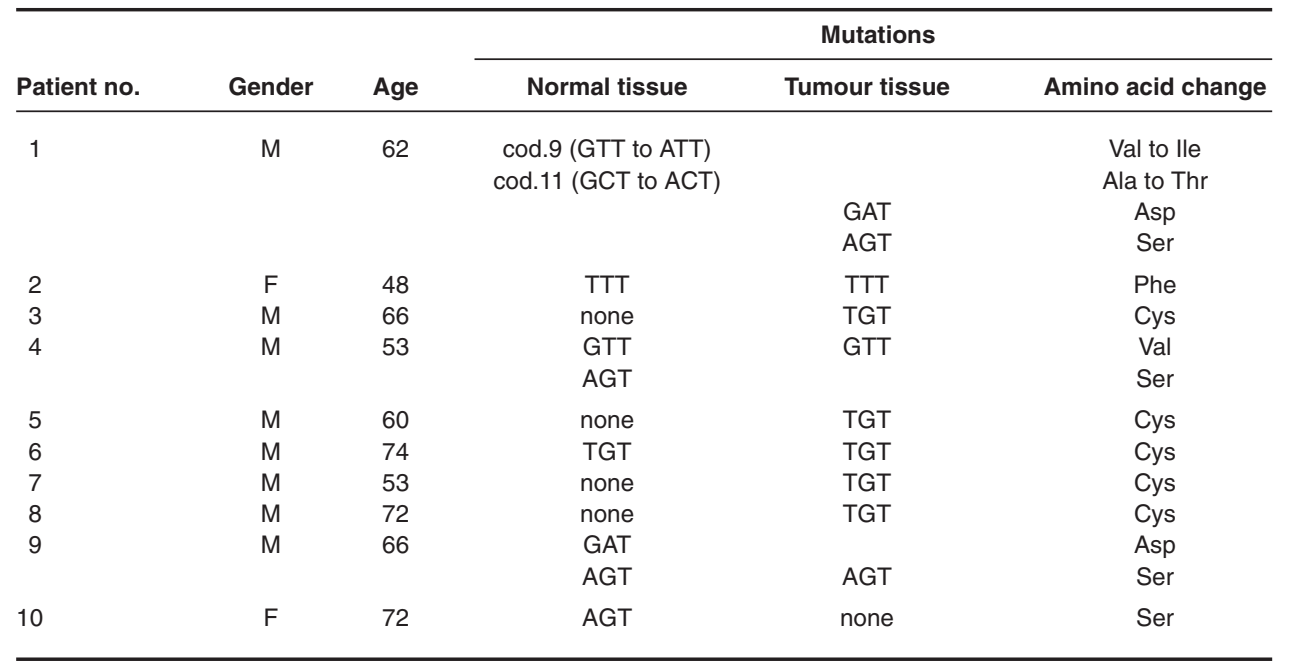

${ }^{a}$ Except for the 2 mutations found in histologically normal tissues in patient 1, all mutations shown involved codon 12 of the K-ras gene.

PCR + DGGE method (see Materials and Methods). Patient 1 contained 2 mutations in codon 12 (a GGT to GAT and GGT to AGT) in tumour tissue and 2 mutations, 1 in codon 9 (a GTT to ATT) and 1 in codon 11 (a GCT to ACT), in histologically normal tissue. These mutations were identified each in only 1 or 2 of the 6 samples taken from either the tumour tissue or the histologically

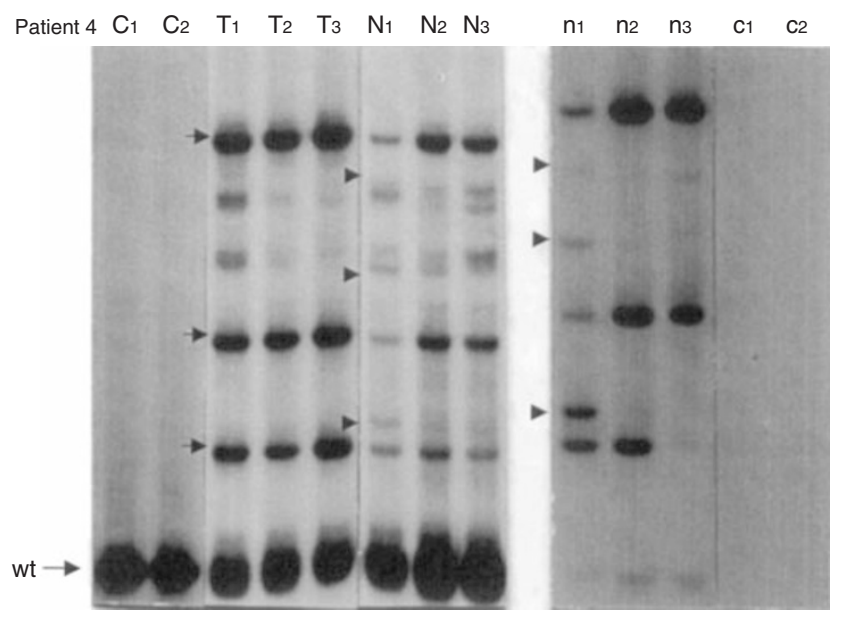

Figure 3 An example of DGGE analysis of K-ras mutations at multiple sites of lung tissue sections for patient 4 shown in Table 1. The figure shows the GGT to GTT mutant sequence pattern in cells sampled at 3 regions of the tumour tissue (T1, T2, T3) and 3 regions of the histologically normal tissue (N1, N2, N3) corresponding to patient 4 . The histologically normal cells were sampled at $5 \mathrm{~cm}$ (N1 and N2) and $2 \mathrm{~cm}$ (N3) from the edge of the tumour. Lanes $\mathrm{C} 1$ and $\mathrm{C} 2$ contained DNA with non-mutated K-ras gene

corresponding to benign lung tissue and infant intestinal tissue, respectively. Shown in lanes $\mathrm{n} 1, \mathrm{n} 2, \mathrm{n} 3$, and $\mathrm{c} 1$ and $\mathrm{c} 2$, are the same DNA from N1, N2, $\mathrm{N} 3$, and $\mathrm{C} 1$ and $\mathrm{C} 2$, that had been first subjected to Banl restriction enzyme digestion to eliminate any non-K-ras codon 12 mutant allele, including the wild-type allele (wt), and thereby to enrich for K-ras codon 12 mutant alleles, then analysed by DGGE (Keohavong et al, 1997). The positions of the mutant homoduplexes (second fragment from $\mathrm{wt}$ ) and the 2 respective mutant/wildtype heteroduplexes (third and fourth fragments from $\mathrm{wt}$ ) were indicated by arrows for the GGT to GTT mutation in lanes T1-T3, and by arrowheads for the GGT to AGT mutation in lanes N1-N3 and n1. After mutant alleleenrichment by Banl digestion, the GGT to AGT mutant pattern in lane N1 appeared more clearly visible in lane $n 1$. As expected, control DNA shown in lanes $\mathrm{c} 1$ and $\mathrm{c} 2$ did not contain any K-ras codon 12 mutant allele normal tissue. In Patient 9, 2 mutations (a GGT to GAT and GGT to AGT) were found in histologically normal tissue and 1 mutation (a GGT to AGT) was found in tumour tissue. In Patient 10, 1 mutation (a GGT to AGT) was found in 2 of 6 samples taken from the histologically normal tissue and in none of 6 malignant cell samples.

\section{DISCUSSION}

Although K-ras mutations have been frequently found in lung tumours and tumour cell lines and implicated in the development of lung cancer, the timing of these mutations in lung carcinogenesis remains poorly understood. There have been several but conflicting reports on whether or not K-ras mutations are present in non-neoplastic or normal-appearing lung tissues, which, in the affirmative, would indicate that they occur early during lung cancer development and can provide an early lung cancer detection marker.

We applied a laser capture microdissection microscope to morphologically review and sample cells at multiple sites from both lung tumour tissue and histologically normal tissue adjacent to as well as those distant from the tumour. Our results, based on independent experiments using successive lung tissue sections from multiple tissue blocks, demonstrated that K-ras mutations were present in histologically normal tissue in 6 of $10(60 \%) \mathrm{K}$-ras mutation-positive lung adenocarcinomas, or 6 of all 38 (15.8\%) lung adenocarcinomas examined. Therefore, K-ras mutations are relatively frequent in histologically normal lung tissue surrounding malignant tissue in lung adenocarcinomas. These mutations can be grouped into high fraction mutations and low fraction mutations in tumour and/or histologically normal tissue. Low fraction K-ras mutations have been previously reported in lung tumour DNA by us and others (Mills et al, 1995; Keohavong et al, 1997a). They were frequently identified in tumour tissue as well as in histologically normal tissue and metastasis (Yakubovskaya et al, 1995). Our present study showed that mutations in patients 1,9 and 10 were detected in only some cell samples taken from malignant tissue and/or matched histologically normal tissue, suggesting that they were not initiating or early events in lung carcinogenesis but rather secondary events accumulating in 
subclones during tumour progression or as a result of continued exposure to tobacco smoke (Mills et al, 1995; Yakubovskaya et al, 1995; Keohavong et al, 1997a). The GTT to ATT mutation (codon 9) and GCT to ACT mutation (codon 11) found in patient 1 had not been reported previously and their biological significance in lung carcinogenesis is not known. Among the lung adenocarcinomas with high fraction mutations, 2 observations can be made. First, these mutations can be found in only the tumour tissue and not in the matched histologically normal tissue (Patients 3, 5, 7 and 8). The fact that they were detected at multiple sites in lung tumour tissue suggests that they may represent events occurring early in small precursor lesions before tumour progression. Secondly, some K-ras mutations are found not only in the tumour tissue but also, at a mutant fraction generally lower than that detected in the tumour tissue, in histologically normal tissues adjacent to as well as those distant from the tumour (Patients 2, 4 and $6)$. These results confirmed our previous study showing that genotypically identical K-ras mutations were detected in both the tumour tissue and, at a lower mutant fraction, in tumour-adjacent normal-appearing tissue in 4 of 8 cases of lung adenocarcinoma (Keohavong et al, 1997). These mutations may represent early events, perhaps initiating events, in the development of these tumours. Furthermore, Patient 4 provides an intriguing example since only 1 mutation, a GGT to GTT, is present in the tumour tissue, but 2 mutations, a GGT to GTT and GGT to AGT, are present in the matched histologically normal tissue. In addition, while the GTT mutation was detected in all samples taken from 6 different sites of the histologically normal tissue, the GGT to AGT mutation was detected in only cell samples taken from a defined area of the normal-appearing tissue distant from the tumour. This observation is compatible with the existence of 2 overlapping fields with each a different mutated K-ras gene, and the field with the GTT mutation may contribute to the development of this tumour (Slaughter et al, 1953; Strong et al, 1984). It is, however, unclear why a field with a specific mutation would have a higher ability to develop into a tumour than one with another mutation type. Some studies suggested that the substitution of the wild-type codon 12 amino acid (glycine) with certain amino acids, including valine and arginine, in the $\mathrm{H}$-ras gene may give rise to gene products with a more potent transforming ability than the wild-type or other amino acids (Seeburgh et al, 1984; Der et al, 1986). It will require an expanded study involving a larger number of lung cancer patients to determine whether our explanation for the observation in patient 4 can be supported.

$\mathrm{K}$-ras mutations were detected in histologically normal mucosal tissues adjacent to or distant from colorectal carcinoma (Pretlow et al, 1991; Minamoto et al, 1995; Zhu et al, 1997). They have been also suggested to be preneoplastic events in pancreatic cancer (Yanagisawa et al, 1993; Berthelemy et al, 1995; Brentall et al, 1995; Tada et al, 1996; Wilentz et al, 1998). However, in lung cancer, there have been conflicting reports on K-ras mutations in non-neoplastic tissues. On the one hand, Santos et al (1984) investigated K-ras codon 12 mutation in lung tissues obtained from a patient with squamous cell carcinoma of the lung and reported that the mutation detected in lung carcinoma was absent from the normal bronchial and parenchymal tissues of that patient. The authors suggested that malignant activation of K-ras oncogene may be specifically associated with the development of a human neoplasm. Sugio et al (1994) reported that K-ras mutations were absent in metaplasia and normal-appearing cells of the lung and were infrequent in dysplastic lesions, suggesting that these mutations are relatively late events in the pathogenesis of lung cancer. Likewise, Urban et al (1996) did not detect any K-ras mutation in non-neoplastic peripheral bronchial or parenchymal tissues associated with lung tumours. Finally, Yakubovskaya et al (1995) detected K-ras mutations in $60 \%$ of normal-appearing lung tissue samples, $63 \%$ of tissue samples from tumour tissue, and $80 \%$ of samples of metastasis obtained from patients with nonsmall cell lung cancer. However, the fact these mutations were present at a low fraction suggests that they did not contribute to the development of lung cancer. On the other hand, the results of these studies are not in agreement with other published studies. For instance, K-ras mutations were identified in atypical alveolar hyperplasia (AAH), a potential precursor from which lung adenocarcinoma arises (Westra et al, 1996). In another study, Clements et al (1995) analysed bronchoscopy specimens obtained from lung cancer patients and showed that K-ras mutations were found in both malignant and nonmalignant tissues in $22.7 \%$ (5 of 22) of the patients and in only nonmalignant tissue in $9.1 \%$ ( 2 of 22 ) of the patients. Finally, a recent study by Urban et al (2000) showed that $\mathrm{K}$-ras mutations were detected in both lung tumour and bronchial carina tissue in $21 \%$ ( 4 of 19) of the patients, while being present only in the bronchial carina but not in the tumour in 11\% (2 of 19) of the patients. These latter studies and our present study showed that K-ras mutations can be frequently found in non-neoplastic lung tissues, including histologically normal tissues.

Questions remain about the usefulness of K-ras mutations as an early detection markers for lung cancer. Mutation in the K-ras gene is a well-established example of the association between environmental exposure (chiefly tobacco smoke) and human lung cancer, since mutations in the K-ras gene are found almost exclusively in lung tumours from smokers, while being rare in lung tumours from non-smokers (Rodenhius and Slebos, 1992; Sugio et al, 1992; Suzuki et al, 1990; Husgafvel-Pursianen et al, 1993; Keohavong et al, 1996; Rosell et al, 1996). In theory, these mutations should be useful markers of exposure to carcinogens in tobacco smoke, and their detection in high-risk individuals without cancer would be an indication of damaged airway epithelium. The presence of these mutations in airways of ex-smokers might also be an indication of persistence of genetic damage in 'condemned epithelium'. The technique of laser capture microdissection as described here could be applied to mucosal biopsies taken by either white light or fluorescent bronchoscopy to determine if K-ras mutations are present in preneoplastic or histologically normal epithelium from the airways of individuals at high risk for lung cancer.

\section{ACKNOWLEDGEMENTS}

This work was supported by a grant from the American Cancer Society (RPG-99-161-01-CNE), and by an NCI grant 1-RO3CA71609-01, and The Veterans Research Foundation of Pittsburgh, Pittsburgh, PA15240.

\section{REFERENCES}

American Cancer Society (2000) Cancer Facts and Figures - 2000. American Cancer Society

Barbacid M (1987) ras genes. Annu Rev Biochem 56: 779-827

Berthelemy P, Bouisson M, Escourrou J, Vaysse N, Rumeau JL and Pradayrol L (1995) Identification of K-ras mutations in pancreatic juice in the early diagnosis of pancreatic cancer. Ann Intern Med 123: 188-191 
Bishop JM (1991) Molecular themes in oncogenes. Cell 64: 235-248

Brentnall TA, Chen R, Lee JG, Kimmey MB, Bronner MP, Haggitt RC, Kowdley KV, Hecker LM and Byrd DR (1995) Microsatellite instability and K-ras mutations associated with pancreatic adenocarcinoma and pancreatitis. Cancer Res 55: 4264-4267

Clements NC, Nelson MA, Wymer JA, Savage C, Aguirre M and Garewal H (1995) Analysis of K-ras gene mutations in malignant and nonmalignant endobronchial tissue obtained by fiberoptic bronchoscopy. Am J Respir Crit Care Med 152: 1374-1378

Der CJ, Finkel T and Cooper GM (1986) Biological and Biochemical properties of human $\mathrm{ras}^{\mathrm{H}}$ genes mutated at codon 61. Cell 44: 167-176

Emmert-Buck MR, Bonner RF, Smith PD, Chuaqui RF, Zhuang Z, Goldstein SR, Weiss RA and Liotta LA (1996) Laser capture microdissection. Science 274: 998-1001

Gazdar AF (1994) The molecular basis of human lung cancer. Anticancer Res 13: $261-268$

Harris CC (1991) Chemical and physical carcinogenesis: advances and perspectives Cancer Res 51: 5023s-5044s

Hollstein M, Sidransky D, Vogelstein B and Harris CC (1991) p53 mutations in human cancers. Science 253: 49-53

Husgafvel-Pursiainen K, Hackman P, Ridanpaa M, Anttila S, Karjalainen A, Partanen T, Taikina-Aho O, Heikkila L and Vaino H (1993) K-ras mutations in human adenocarcinoma of the lung: association with smoking and exposure to asbestos. Int J Cancer 53: 250-256

Keohavong P, DeMichele MAA, Melacrinos AC, Landreneau RJ, Weyant RJ and Siegfried JM (1996) Detection of K-ras mutations in lung carcinomas: Relationship to prognosis. Clin Cancer Res 2: 411-418

Keohavong P, Zhu D, Melacrinos AC, DeMichele MAA, Weyant RJ, Luketich JD, Testa JR, Fedder M and Siegfried JM (1997a) Detection of low-fraction K-ras mutations in primary lung tumors using sensitive methods. Int J Cancer 74: $162-170$

Keohavong P, Zhu D, Whiteside TL, Swalsky P, Bakker A, Elder EM, Siegfried JM, Srivastava S and Finkelstein SD (1997b) Detection of infrequent and multiple $\mathrm{K}$-ras mutations in human tumors and tumor-adjacent tissues. Anal Biochem 247: 394-403

Khosravi-Far R and Der CJ (1994) The ras signal transduction pathway. Cancer Metast Rev 13: 67-89

Li ZH, Zheng J, Weiss LM and Shibata D (1994) c-K-ras and p53 mutations occur very early in adenocarcinoma of the lung. Am J Pathol 144: 303-309

Marshall CJ (1991) Tumor suppressor genes. Cell 64: 313-326

Mills NE, Fishman CL, Rom WN, Dubin N and Jacobson DR (1995) Increased prevalence of K-ras oncogene mutations in lung adenocarcinoma. Cancer Res 55: $1444-1447$

Minamoto T, Yamashita N, Ochiai A, Mai M, Sugimura T, Ronai Z and Esumi H (1995) Mutant K-ras in apparently normal mucosa of colorectal cancer patients: its potential as a biomarker of colorectal tumorigenesis. Cancer $\mathbf{7 5}$ : $1520-1526$

Minna JD, Pass H, Glatstein E and Ihde DC (1989) Lung cancer. In: Principles and Practice of Oncology. deVita VT, Rosenberg S and Hellman S (eds). pp. 591-705. Lippincott JB: Philadelphia

Pretlow TP, Barrow BJ, Ashton WS, O'Riordan MA, Pretlow TG, Jurcisek JA and Stellato TA (1991) Aberrant crypts: putative preneoplastic foci in human colonic mucosa. Cancer Res 51: 1564-1567

Rodenhuis S and Slebos RJ (1992) Clinical significance of ras oncogene activation in human lung cancer. Cancer Res 52: 2665s-2669s

Rosell R, Monzo M, Pifarre A, Ariza A, Sanchez JJ, Moreno I, Maurel J, Lopez M, Abad A and de Anta JM (1996) Molecular staging of non-small cell lung cancer according to K-ras genotypes. Clin Cancer Res $\mathbf{2}$ : $1083-1086$
Santos E, Martin-Zanca D, Reddy EP, Pierotti MA, Della Porta G and Barbacid M (1984) Malignant activation of a K-ras oncogene in lung carcinoma but not in normal tissue of the same patient. Science 223: 661-664

Seeburgh PH, Colby WW, Capon DJ, Goeddel DV and Levinson AD (1984) Biological properties of human c-H-ras genes mutated at codon 12. Nature (Lond.) 312: 71-75

Slaughter TP, Southwick HW and Smejkel W (1953) Field cancerization in oral stratified epithelium. Cancer 6: 963-968

Sozzi G, Miozzo M, Pastorino U, Pilotti S, Donghi R, Giarola M, Gregorio LD, Manenti G, Radice P, Minoletti F, Porta GD and Pierotti MA (1995) Genetic evidence for an independent origin of multiple preneoplastic and neoplastic lung lesion. Cancer Res 55: 135-140

Stanley LA (1995) Molecular aspects of chemical carcinogenesis: the roles of oncogenes and tumor suppressor genes. Toxicology 96: 173-194

Strong MS, Incze J and Vaughan CW (1984) Field cancerization in the aerodigestive tract - its etiology, manifestation, and significance. J Ontolaryn 13: 1-6

Sugio K, Ishida T, Yokoyama H, Inoue T, Sugimachi K and Sasazuki T (1992) ras gene mutation as a prognostic marker in adenocarcinoma of the human lung without lymph node metastasis. Cancer Res 52: 2903-2906

Sugio K, Kishimoto Y, Virmani AK, Hung JY and Gazdar AF (1994) K-ras mutations are relatively late event in the pathogenesis of lung carcinomas. Cancer Res 54: 5811-5815

Suzuki Y, Orita M, Shiraishi M, Hayashi K and Sekiya T (1990) Detection of ras gene mutations in human lung cancer by single-stranded conformational polymorphism analysis of polymerase chain reaction products. Oncogene $\mathbf{5}$ $1037-1043$

Tada M, Ohashi M, Shiratori Y, Okudaira T, Komatsu Y, Kawabe T, Yoshida H, Machinami R, Kishi K and Omata M (1996) Analysis of K-ras gene mutation in hyperplastic duct cells of the pancreas without pancreatic disease. Gastroenterology 110: 227-231

Urban T, Ricci S, Lacave R, Antoine M, Kambouchner M, Capron F and Bernaudin JF (1996) Codon $12 \mathrm{Ki}$-ras mutation in non-small-cell lung cancer: comparative evaluation in tumoural and non-tumoural lung. Brit J Cancer 74: $1051-1055$

Urban T, Ricci S, Danel C, Antoine M, Kambouchner M, Godard V, Lacave R and Bernaudin JF (2000) Detection of codon $12 \mathrm{~K}$-ras mutations in non-neoplastic mucosa from bronchial carina in patients with lung cancer. Brit J cancer $\mathbf{8 2}$ : $412-417$

Westra WH, Slebos RJ, Offerhaus GJ, Goodman SN, Evers SG, Kensler TW, Askin FB, Rodenhius S and Hruban RH (1993) K-ras oncogene activation in lung adenocarcinomas from former smokers. Cancer 72: 432-438

Westra WH, Baas IO, Hruban RH, Askin FB, Wilson K, Offenhaus GJA and Slebos RJC (1996) K-ras oncogene activation in atypical alveolar hyperplasia of the human lung. Cancer Res 56: 2224-2228

Wilentz RE, Chung CH, Sturm PD, Musler A, Sohn TA, Offerhaus GJ, Yeo CJ, Hruban RH and Slebos RJ (1998) K-ras mutations in the duodenal fluid of patients with pancreatic carcinoma. Cancer 82: 96-103

Yakubovskaya MS, Spiegelman V, Luo FC, Malaev F, Salnew A, Zborovskaya I, Gasparian A, Polotsky B, Machaladze Z, Trachtenberg AC, Belitsky GA and Ronai Z (1995) High frequency of K-ras mutations in normal appearing lung tissues and sputum of patients with lung cancer. Int J Cancer 63: 810-814

Yanagisawa A, Ohtake K, Ohashi K, Hori M, Kitagawa T, Sugano H and Kato Y (1993) Frequent c-Ki-ras oncogene activation in mucous cell hyperplasias of pancreas suffering from chronic inflammation. Cancer Res 53: 953-956

Zhu D, Keohavong P, Finkelstein SD, Swalska P, Bakker A, Weissfeld J, Srivastava $\mathrm{S}$ and Whiteside TL (1997) K-ras mutations in normal colorectal tissues from K-ras mutation-positive colorectal cancer patients. Cancer Res 57: $2485-2492$ 